\title{
Seroprevalence of Hepatitis B Among Municipal Waste Collectors in Penang Island, Malaysia and Their Knowledge, Attitude and Practice Towards the Prevention of Hepatitis B
}

\author{
Siti Fatimah Kader Maideen ${ }^{1}$, Fairuz Fadzilah Rahim ${ }^{1}$, Abdul Rashid ${ }^{1} \&$ Surajudeen Abdulrahman ${ }^{2}$ \\ ${ }^{1}$ Department of Public Health Medicine, RCSI \& UCD Malaysia Campus, No.4, Jalan Sepoy Lines, 10450 George \\ Town, Penang Malaysia \\ ${ }^{2}$ Academic Clinical Fellow, James Paget University Hospital, Lowestoft Road, Gorleston, Great Yarmouth, \\ Norfolk, United Kingdom \\ Correspondence: Siti Fatimah Kader Maideen, Department of Public Health Medicine, RCSI \& UCD Malaysia \\ Campus, No.4, Jalan Sepoy Lines, 10450 George Town, Penang Malaysia. Tel: 604-217 1972. Fax: 604-228-4285. \\ E-mail: sitifatimah@rcsiucd.edu.my
}

Received: January 16, 2020 Accepted: April 8, 2020 Online Published: May 8, 2020

doi:10.5539/gjhs.v12n7p20 URL: https://doi.org/10.5539/gjhs.v12n7p20

\begin{abstract}
While there are many risks that increase an individuals' exposure to infectious diseases such as Hepatitis B, occupational exposure increases one's risk to acquire such infections. The objective of this study was to determine the prevalence of Hepatitis B among municipal solid waste collectors and their knowledge, attitude and practice towards the prevention of Hepatitis B. An analytical cross-sectional study was carried out among solid waste collectors in Penang Island from November 2017 to Mei 2018. The inclusion criteria of this study were solid waste collectors who have been working for at least 6 months and able to understand either Malay or English language. Those who did not turn up during the data collection period and who were unable to give their blood sample were excluded from the study. Participants' blood were tested for Hepatitis B surface antigen (HBsAg) and Hepatitis B surface antibody (HBsAb) using Elisa. The waste collectors were then interviewed using a structured questionnaire. Ethical approval was obtained from the Institutional Research Ethics Committee, PMC RC-14. A total of 184 out of 221 eligible waste handlers participated in the study, giving a response rate of $83.3 \%$. The prevalence of Hepatitis B in this study was $1.6 \%$. Significant correlation was observed between attitude and practice scores $(r=0.203, p=0.006)$. The prevalence of Hepatitis B among municipal waste collectors was low in this study. Most had poor knowledge in regards to Hepatitis B. Empowering workers by providing them adequate information is essential to reduce the risk of contracting the disease.
\end{abstract}

Keywords: Hepatitis B, municipal solid waste collectors, prevalence, KAP, Malaysia

\section{Introduction}

Hepatitis B is an infectious disease caused by Hepatitis B virus, which is able to cause both acute and chronic liver disease. Hepatitis B infection is a life threatening and can have a debilitating effect in people with chronic form of the infection leadings to liver cirrhosis and hepatocellular carcinoma. Globally, it is estimated that in 2015,257 million people were infected with chronic Hepatitis B Viral (HBV) infection (World Health Organization, 2017). In the same year, 887000 people died as a result of this infection. The prevalence of HBV infection has been reported to be the highest in the Western Pacific and African region (World Health Organization, 2017). In Malaysia, the seroprevalence of Hepatitis B infection in the general population ranged from 1.5-9.8\%, affecting one million of the population with chronic Hepatitis B infection (Raihan, 2016).

The transmission routes of Hepatitis B include mucosal and percutaneous exposure with blood or body fluids such as saliva, vaginal and seminal fluids; usage of needles, syringes, razors or sharp items contaminated with blood, sexual and mother to child transmissions (Centers for Disease Control and Prevention, 2001). While there are many risk that increases one's exposure towards infectious diseases such as Hepatitis B, Hepatitis C, HIV, leptospirosis and many other diseases; certain occupations carry higher risks to such infections. Hepatitis B has been found to be higher among healthcare professionals, sex workers, clinical waste handlers, scrap metal collectors and the domestic waste handlers. In a systematic review and meta-analysis, it was found that the pooled 
prevalence of Hepatitis B among the waste handlers was 11\% (Corrao, Cimmuto, Marzuillo, Paparo, \& Torre, 2013). In another study in central Brazil, the prevalence of Hepatitis B among recyclable waste collectors was $12.8 \%$ (Marinho et al., 2014). Slightly lower prevalence of HBV of 7\% was reported among municipal solid waste workers in Greece (Dounias, Kypraiou, Rachiotis, Tsovili, \& Kostopoulos, 2005).

One of the common method of transmission of Hepatitis B among waste collectors is due to sharp item injury. A study done among municipal waste collectors in Greece reported that exposure to sharp instruments and injury due to needle sticks are possible medium of transmission of Hepatitis B (Tsovili et al., 2014). Collecting garbage bare-handed is seen as one of the most common practices among waste collectors which put them at risk of contracting Hepatitis B (Abdul Rauf et al., 2013).

Poor knowledge, attitudes and practice can be a reason for the higher rates of infections among those at risks in certain occupations. Poor knowledge, attitude and practices towards Hepatitis B was found among general population in Pakistan (Haq et al., 2012). Similarly, low knowledge regarding Hepatitis B was reported among migrant workers in Shandong, China (Yang et al., 2015). A study in Ethiopia reported only about half of the medical waste handlers had knowledge of viral hepatitis (Shiferaw, Abebe, \& Mihret, 2011).

While the prevalence of Hepatitis B among municipal solid waste collectors is well known in other parts of the world, there has been no published report among these population in Malaysia. Considering these group of people are at higher risk of contracting Hepatitis B due to their occupation, it is important to determine the prevalence of Hepatitis B infection among them and to assess their knowledge, attitude and practice towards the prevention of Hepatitis B.

\section{Methodology}

\subsection{Study Design}

An analytical cross-sectional study was conducted in Penang Island, Malaysia.

\subsection{Settings}

Malaysia is a country located in South East Asia and consists of 13 states and three federal territories. Penang is located in the Northwest coast of Peninsular Malaysia and consists of Penang Island and Penang mainland. This study was conducted in the Island of Penang. Local municipal council in Penang Island manages the administration of the island. The council selects contractors for the management of waste, which includes the collection, transportation and disposal of the waste. At the time the study was conducted, there were nine contractors which were responsible for collecting garbage in the Penang Island. The waste collectors from all the nine contractors were eligible to participate in this study.

\subsection{Sampling Method}

The name list of the contractors was obtained from the local municipal council. The waste handlers in these companies were briefed in detail concerning the study individually. Only upon receiving a written consent from the waste handlers, were they recruited in the study. Each of the companies had approximately 25 waste handlers who were involved in the collection of the waste. Due to the different working shifts, a convenience sampling was used to select the participants for this study.

\subsection{Procedures of Data Collection}

The data collection commenced in November 2017 and completed in Mei 2018. Data were collected by three researchers, assisted by a trained research assistant. The participants were briefed regarding the purpose of the study, tests that would be taken, benefits and risk of taking part in the research, confidentiality of the information and option to withdraw from the study should they change their mind. After the detailed explanation, they were provided with an information sheet, once they understood the information, they fill up the consent form. For those who were able to write, they signed the consent form while for those were unable to sign, their thumb print were taken with the presence of a witness. An ID number was assigned to each of the participant. The same ID was used by the laboratory personnel for blood sample identification.

The data collection process involved two steps. The first step involved blood sample collection. Participants' blood was withdrawn and their serum were tested for Hepatitis B surface antigen (HBsAg) and Hepatitis B surface antibody (HBsAb) using Elisa method. A result of reactive HBsAg indicates that the person is infected with Hepatitis $\mathrm{B}$ infection and is infectious. While a result of reactive for $\mathrm{HBsAb}$ indicates that the person is protected against Hepatitis B virus resulting from either Hepatitis B vaccination or recovery from past Hepatitis B infection. The second step involved interviewing the waste handlers on the knowledge, attitude and practices regarding the prevention of Hepatitis B using a structured questionnaire in Malay language. The interview took about 20 minutes 
to complete. Completeness of the questionnaires was checked before ending the interview. The flow chart of the data collection is shown in Figure 1.

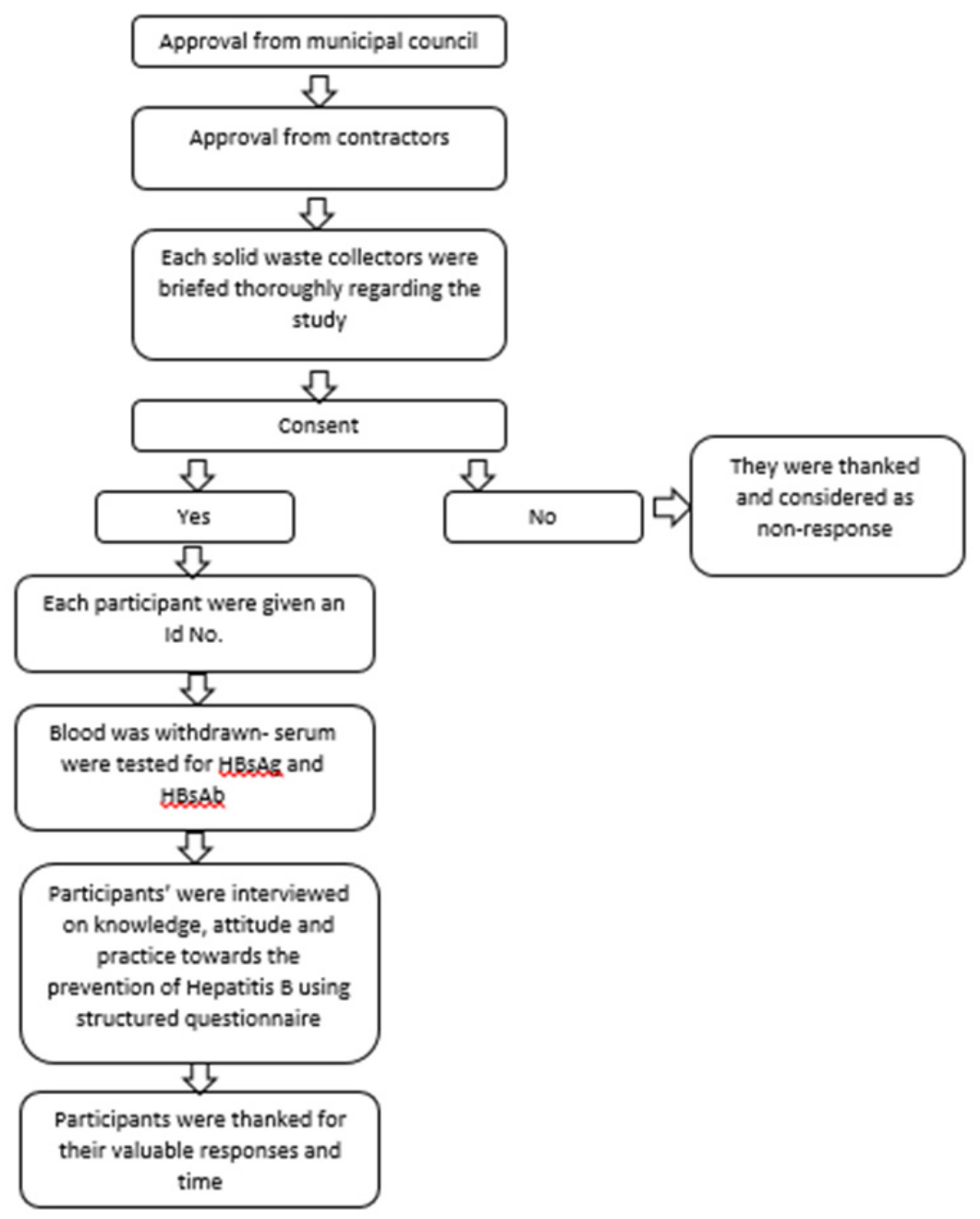

Figure 1. The flow chart of the data collection

\subsection{Selection Criteria}

The sample population of this study was waste handlers of the nine contractors working in Penang Island. Most of them were foreign workers from multiple Asian countries. They were mainly involved in the collection of domestic waste and were exposed to various waste secretions.

The inclusion criteria of this study were waste handlers who have been working in this line for at least 6 months and able to understand either Malay or English language. Those who did not turn up during the data collection period and who were unable to give their blood sample were excluded from the study.

\subsection{Variables}

The outcome variables are knowledge, attitude and practice regarding prevention of Hepatitis B while the independent variables are the socio-demographic variables.

\subsection{Questionnaires}

A structured questionnaire on knowledge, attitude and practice towards the prevention of Hepatitis B infection was developed based on the information from literature search. Section 1 consists of items on socio-demographic characteristics such as age, marital status, education level and etc. Section 2 assessed items on knowledge of Hepatitis B, which consisted of 24 items. Each item was assessed using three options (yes, no and unsure). Each correct answer was given one mark while a wrong and unsure option was given a 0 mark. The knowledge scores 
ranged from 0 to 24 . A mean score of the total items was used to categorize into good and poor knowledge. Section 3 which consist of 8 items on a five-point Likert scale assessed the attitudes towards prevention of Hepatitis B. The attitude scores ranged from 0 to 40 . A mean score of the total items was used to categorize into good and poor attitude. Section 4 assessed the practices towards prevention of Hepatitis B. This section consisted of 10 items; with each item having two options, yes and no. Each appropriate practice was given 1 mark while for each inappropriate practice, a 0 mark was given. The practice scores ranged from 0 to 10 . A mean score of the total items was used to categorize into good and poor practice.

\subsection{Data Analysis}

Data was entered in Excel and imported into SPSS for analysis. Descriptive statistics was used to describe the participants. For continuous variables, mean and standard deviation were displayed. While for the categorical variables, frequency and percentages were displayed. Chi-square test or Fisher Exact test was used to determine the association between categorical variables, such as education level and the outcome (good and poor knowledge) A simple logistic regression was used to determine the mean difference in age and income between the two groups (good and poor knowledge). P-values of less than 0.05 was considered to be statistically significant.

\subsection{Ethical Statement}

Ethical approval was obtained from the Institutional Research Ethics Committee (PMC RC-14). Written consent was obtained from all the participants.

\section{Results}

A total of 184 out of 221 eligible waste collectors participated in the study, giving a response rate of $83.3 \%$. The reasons for non-participation were mainly due to working in a different shifts during the period of data collection, sick and not interested in participating in the study.

Table 1. Socio-demographic characteristics of the participants $(\mathrm{N}=184)$.

\begin{tabular}{lcc}
\hline Socio-demographic characteristics & Frequency (n) & Percentage (\%) \\
\hline Marital status & 43 & 23.4 \\
Single & 141 & 76.6 \\
Married & & \\
\hline Nationality & 138 & 75.0 \\
Bangladesh & 38 & 20.7 \\
Indonesia & 3 & 1.6 \\
Nepal & 5 & 2.7 \\
Malaysia & & \\
\hline Education level & 33 & 18.3 \\
Informal & 78 & 43.3 \\
Primary & 23 & 12.8 \\
Secondary & 46 & 25.6 \\
Tertiary & & \\
\hline
\end{tabular}

The age of the participants ranged from 18 to 68 , with a mean age of $35.4 \pm 7.2$ years. All the participants were men. Majority of the participants were married (76.6), and were Bangladesh nationals (75.0\%), attained primary education (42.4\%) and with median monthly income of RM 1000.00. Table 1 shows the socio-demographic characteristics of the study participants. Half of the participants reported they had been vaccinated previously, however were not sure of vaccination received for which type of disease. 
Table 2. Seroprevalence of Hepatitis B among the participants.

\begin{tabular}{lcc}
\hline & Frequency (n) & Percentage (\%) \\
\hline Hepatitis B surface antigen & 3 & 1.6 \\
Reactive & 181 & 98.4 \\
Non-reactive & & \\
\hline Hepatitis B surface antibody & 23 & 12.5 \\
Reactive & 161 & 87.5 \\
Non-reactive & & \\
\hline
\end{tabular}

The prevalence of Hepatitis B in this study was $1.6 \%(n=3)$. A total of $12.5 \%(n=23)$ of the participants have antibody towards Hepatitis B which could be either due to recovery from previous Hepatitis B infection or immunity received from Hepatitis B vaccination (Table 2).

Majority of the participants have poor knowledge $(77.0 \%, \mathrm{n}=141)$ on Hepatitis B. However, more than half of them had good attitude $(53.6 \%, \mathrm{n}=98)$ and majority had good practice $(73.9 \%, \mathrm{n}=136)$.

Table 3. The association between socio-demographic characteristics with knowledge, attitude and practice towards Hepatitis B

\begin{tabular}{|c|c|c|c|c|c|c|c|c|c|}
\hline \multirow[b]{2}{*}{$\begin{array}{l}\text { Socio-demographic } \\
\text { characteristics }\end{array}$} & \multicolumn{3}{|c|}{ Knowledge } & \multicolumn{3}{|c|}{ Attitude } & \multicolumn{3}{|c|}{ Practice } \\
\hline & $\begin{array}{l}\text { Poor } \\
\text { n (\%) }\end{array}$ & $\begin{array}{l}\text { Good } \\
\text { n (\%) }\end{array}$ & $\begin{array}{l}\text { OR }(95 \% \mathrm{CI}) / \\
\text { p-value }\end{array}$ & $\begin{array}{l}\text { Poor } \\
\text { n (\%) }\end{array}$ & $\begin{array}{l}\text { Good } \\
\text { n (\%) }\end{array}$ & $\begin{array}{l}\text { OR }(95 \% \mathrm{CI}) / \\
\text { p-value }\end{array}$ & $\begin{array}{l}\text { Poor } \\
\text { n (\%) }\end{array}$ & $\begin{array}{l}\text { Good } \\
\text { n (\%) }\end{array}$ & $\begin{array}{l}\text { OR }(95 \% \mathrm{CI}) / \\
\text { p-value }\end{array}$ \\
\hline \multicolumn{10}{|l|}{ Marital status } \\
\hline Single & $\begin{array}{l}32 \\
(22.7)\end{array}$ & $\begin{array}{l}11 \\
(26.2)\end{array}$ & $\begin{array}{ll}0.827 & (0.374 \\
-1.828) / 0.639\end{array}$ & $\begin{array}{l}16 \\
(18.8)\end{array}$ & $\begin{array}{l}27 \\
(27.6)\end{array}$ & Ref & $\begin{array}{l}11 \\
(22.9)\end{array}$ & $\begin{array}{l}32 \\
(23.5)\end{array}$ & Ref \\
\hline Married & $\begin{array}{l}109 \\
(77.3)\end{array}$ & $\begin{array}{l}31 \\
(73.8)\end{array}$ & Ref & $\begin{array}{l}69 \\
(81.2)\end{array}$ & $\begin{array}{l}71 \\
(72.4)\end{array}$ & $\begin{array}{l}0.610(0.302-1.230) / \\
0.167\end{array}$ & $\begin{array}{l}37 \\
(77.1)\end{array}$ & $\begin{array}{l}104 \\
(76.5)\end{array}$ & $\begin{array}{l}1.035 \\
(0.474-2.260) / \\
0.931\end{array}$ \\
\hline \multicolumn{10}{|l|}{ Nationality } \\
\hline Bangladesh & $\begin{array}{l}115 \\
(83.9)\end{array}$ & $\begin{array}{l}22 \\
(53.7)\end{array}$ & $\begin{array}{l}4.514 \\
(2.101-9.699) / \\
<0.001^{*}\end{array}$ & $\begin{array}{l}68 \\
(82.9)\end{array}$ & $\begin{array}{l}69 \\
(71.9)\end{array}$ & $\begin{array}{l}0.526 \\
(0.254-1.089) / 0.081\end{array}$ & $\begin{array}{l}32 \\
(68.1)\end{array}$ & $\begin{array}{l}106 \\
(80.3)\end{array}$ & $\begin{array}{l}1.911 \\
(0.904-4.039) / \\
0.087\end{array}$ \\
\hline Others & $\begin{array}{l}22 \\
(16.1)\end{array}$ & $\begin{array}{l}19 \\
(46.3)\end{array}$ & Ref & $\begin{array}{l}14 \\
(17.1)\end{array}$ & $\begin{array}{l}27 \\
(28.1)\end{array}$ & Ref & $\begin{array}{l}15 \\
(31.9)\end{array}$ & $\begin{array}{l}26 \\
(19.7)\end{array}$ & Ref \\
\hline \multicolumn{10}{|l|}{ Education level } \\
\hline $\begin{array}{l}\text { Lower secondary and } \\
\text { below }\end{array}$ & $\begin{array}{l}108 \\
(76.6)\end{array}$ & $\begin{array}{l}25 \\
(59.5)\end{array}$ & $\begin{array}{l}2.225 \\
(1.073-4.614) \\
/ 0.029 *\end{array}$ & $\begin{array}{l}67 \\
(78.8)\end{array}$ & $\begin{array}{l}66 \\
(67.3)\end{array}$ & $\begin{array}{l}0.554(0.284-1.083) \\
/ 0.082\end{array}$ & $\begin{array}{l}40 \\
(83.3)\end{array}$ & $\begin{array}{l}94 \\
(69.1)\end{array}$ & $\begin{array}{l}0.448 \\
(0.193-1.039) \\
/ 0.057\end{array}$ \\
\hline $\begin{array}{l}\text { Upper secondary and } \\
\text { above }\end{array}$ & $\begin{array}{l}33 \\
(23.4)\end{array}$ & $\begin{array}{l}17 \\
(40.5)\end{array}$ & Ref & $\begin{array}{l}18 \\
(21.2)\end{array}$ & $\begin{array}{l}32 \\
(32.7)\end{array}$ & Ref & $\begin{array}{l}8 \\
(16.7)\end{array}$ & $\begin{array}{l}42 \\
(30.9)\end{array}$ & Ref \\
\hline
\end{tabular}




\begin{tabular}{|c|c|c|c|c|c|c|c|c|c|}
\hline $\begin{array}{l}\text { Age, } \\
\text { Mean } \\
(95 \% \\
\text { CI) }\end{array}$ & $\begin{array}{l}35.60 \\
(34.36, \\
36.83)\end{array}$ & $\begin{array}{l}34.56 \\
(32.58, \\
36.62)\end{array}$ & $\begin{array}{l}1.020 \\
(0.971-1 . \\
071) / \\
0.433\end{array}$ & $\begin{array}{l}35.91 \\
(34.49, \\
37.34)\end{array}$ & $\begin{array}{l}34.90 \\
(33.36- \\
36.45)\end{array}$ & $\begin{array}{l}0.980 \\
(0.941-1.0 \\
22) / 0.344\end{array}$ & $\begin{array}{l}34.86 \\
(33.14-36.5 \\
9)\end{array}$ & $\begin{array}{l}35.54 \\
(34.25-36.8 \\
3)\end{array}$ & $\begin{array}{l}1.013 \\
(0.967-1 . \\
062) / \\
0.576\end{array}$ \\
\hline $\begin{array}{l}\text { Inco } \\
\text { me }\end{array}$ & $\begin{array}{l}1116.56 \\
(1084.21-11 \\
48.91)\end{array}$ & $\begin{array}{l}1147.62 \\
(1066.11-12 \\
29.12)\end{array}$ & $\begin{array}{l}0.999 \\
(0.998-1 . \\
001) / \\
0.404\end{array}$ & $\begin{array}{l}1157.71 \\
(1107.33-12 \\
08.08)\end{array}$ & $\begin{array}{l}1085 \\
(1052.63-11 \\
17.37)\end{array}$ & $\begin{array}{l}0.998 \\
(0.9965-0 . \\
9997) / \\
0.018^{*}\end{array}$ & $\begin{array}{l}1126.46 \\
(1064.06-11 \\
88.86)\end{array}$ & $\begin{array}{l}1122.54 \\
(1086.93-11 \\
58.14)\end{array}$ & $\begin{array}{l}1.000 \\
(0.998-1 . \\
001) / \\
0.911\end{array}$ \\
\hline $\begin{array}{l}\text { Durat } \\
\text { ion of } \\
\text { worki } \\
\text { ng as } \\
\text { waste } \\
\text { handl } \\
\text { ers }\end{array}$ & $\begin{array}{l}5.61 \\
(4.88-6.34)\end{array}$ & $\begin{array}{l}5.88 \\
(4.71-7.04)\end{array}$ & $\begin{array}{l}0.986 \\
(0.909-1 . \\
068) / \\
0.722\end{array}$ & $\begin{array}{l}5.73 \\
(4.88-6.59)\end{array}$ & $\begin{array}{l}5.54 \\
(4.64-6.43)\end{array}$ & $\begin{array}{l}0.989 \\
(0.923-1.0 \\
60) / 0.752\end{array}$ & $\begin{array}{l}5.77 \\
(4.65-6.89)\end{array}$ & $\begin{array}{l}5.62 \\
(4.88-6.36)\end{array}$ & $\begin{array}{l}0.992 \\
(0.918-1 . \\
072) / \\
0.834\end{array}$ \\
\hline
\end{tabular}

* Significance at $\mathrm{p}$-value $<0.05$.

Table 3 shows the association between socio-demographic characteristics with knowledge, attitude and practice towards Hepatitis B. Nationality $(\mathrm{p}<0.001)$ and education level $(\mathrm{p}=0.029)$ were significantly associated with knowledge. Income was significantly associated with attitude $(\mathrm{p}=0.018)$. None of the socio-demographic characteristics were associated with practice.

Table 4. The correlation between knowledge, attitude and practice scores

\begin{tabular}{lccc}
\hline \multirow{2}{*}{ Variables } & Knowledge scores & Attitude scores & Practice scores \\
\cline { 2 - 4 } & $\begin{array}{c}\text { Correlation coefficient/ } \\
\text { p-value }\end{array}$ & $\begin{array}{c}\text { Correlation coefficient/ } \\
\text { p-value }\end{array}$ & $\begin{array}{c}\text { Correlation coefficient/ } \\
\text { p-value }\end{array}$ \\
\hline Knowledge scores & - & $0.020 / 0.786$ & $-0.091 / 0.219$ \\
Attitude scores & $0.020 / 0.786$ & - & $0.203 / 0.006$ \\
Practice scores & $-0.091 / 0.219$ & $0.203 / 0.006^{*}$ & - \\
\hline
\end{tabular}

*Significance at $\mathrm{p}$-value $<0.001$.

The correlation between the knowledge, attitude and practice scores is shown in Table 4. Statistically significant correlation was found between attitude scores and practice scores $(\mathrm{r}=0.203, \mathrm{p}=0.006)$. No correlation was observed between knowledge scores and attitude scores nor with knowledge scores and practice scores. The results affirms the relationship between attitude and practice in the prevention of Hepatitis B infection.

\section{Discussion}

The seroprevalence of Hepatitis B among municipal solid waste collectors in this study was $1.6 \%$, which is very low as compared to various other studies. Higher prevalence of Hepatitis B was observed among municipal solid waste workers in Greece of 7\% (Dounias et al., 2005), $3.99 \%$ among factory workers in Pakistan (Ilyas, Iftikhar, Rasheed, \& Yasmin, 2012), 5.9\% among public cleansing workers in Thailand (Luksamijarulkul, Sujirarat, \& Charupoonphol, 2008), 15\% among waste collectors in Greece (Tsovili et al., 2014), 17.4\% among scavengers in Nigeria (Yusuf, Sawyerr, Adeolu, Habeeb, \& Abolayo, 2018), 18.8\% among garbage scavengers in Karachi (Abdul Rauf et al., 2013) and 61.8\% among patients in Monte Negro (Khouri et al., 2005). Slightly lower prevalence, $0.7 \%$ of prevalence was noted among recyclable waste collectors in Brazil (Marinho et al., 2014). A systematic review and meta-analysis reported a pooled prevalence of Hepatitis B of $11 \%$ among solid waste workers (Corrao et al., 2013).

Mandatory screening of Hepatitis B among the foreign workers before being employed in the company was the main reason for the low prevalence of Hepatitis B in this study. Each foreign worker has to complete their medical examination in their respective country prior to arrival in Malaysia. Within 30 days of entry into Malaysia, they are again required to undergo another medical examination. The medical examination of the foreign workers is carried 
out by a company appointed by the Government, Foreign Workers Medical Examination Monitoring Agency (FOMEMA). The health screening process is conducted with the intention of preventing the spread of infectious diseases such as Hepatitis B, HIV, Tuberculosis, Malaria and other diseases into Malaysia from abroad. Municipal solid workers are recommended to take Hepatitis B vaccination to protect them from acquiring this disease in which the payment usually borne by the workers itself or in some instances the company sponsor the vaccination fee. Safety measures should always be at the top hierarchy of prioritization to reduce one's risk of contracting infectious diseases such as Hepatitis B (Bleck \& Wettberg, 2012). Besides that, the lowest prevalence of Hepatitis $\mathrm{B}$ in this study also could be attributed to the implementation of waste segregation and recommendation of recycling of reusable materials in Penang.

It is expected solid waste collectors to have poor knowledge in regards of Hepatitis B due to their lower education levels. Similarly, the participants in the study were noted to have poor knowledge. Lack of health education campaigns targeting hepatitis B among this population could have contributed to the poor knowledge. Having sufficient knowledge and proper attitudes toward hepatitis B are foundations for preventing the spread of the disease. Empowering workers by providing them adequate information concerning Hepatitis B including the risks of contracting the diseases and precautionary measures such as using personal protective equipment can help in preventing and controlling the infection.

Nevertheless, it was found that the workers have moderate attitude and good practices towards the prevention of Hepatitis B. The attitude and practice of the workers were better as compared to their knowledge which could be due to the workers were still mindful that they are at risk of contracting diseases since they are collecting filthy materials. Besides that, the presence of detailed clear policies related to waste management and standard operating procedures could have led to the good practices among the waste collectors. In addition, regular strict monitoring on the worker's practices by the employers and the council, and the fear of losing their job should they disobey the rules and regulations has helped encourage good practice among the waste collectors.

This study noted a statistically significant correlation between attitude scores and practice scores. Workers who showed better attitude were reported to have good practices towards the prevention of Hepatitis B infection. This findings is similar to a study done by Barloa et al. who found students with better attitude showed better practices in solid waste management (Barloa, Lapie, \& de la Cruz, 2016). Study showed that participants with good attitude was shown to have good practice towards waste management (Laor et al., 2018). The correlation between attitude and practice can also be explained by theory of Planned Behavior which illuminated that action is often influenced by one's attitude, the norm and perceived behavioral control (Ajzen, 1991). Attitude predisposes one on cognitive, affective and conative responses, in turn affects one's behavior (Ajzen, 1993).

There were numerous strengths in this study that worth mentioning. First, this is the first study to evaluate the seroprevalence of Hepatitis B among municipal solid waste handlers in Penang. Besides that, face-to-face interview which was carried out has increased the response rate and the clarity and accuracy of the responses from the participants. Nevertheless, the study also has some limitations. First, the cross-sectional study design which were deployed limits the temporal relationship and causality inference. Second, the study is subjected to information and recall bias. However, each of the participants were given sufficient time to think carefully before responding to their questions. A convenience sampling had to be used due to the small number of workers in a company and different shift, which limits the generalizability of the findings. Therefore the findings of this study should be interpreted with caution.

\section{Conclusion}

The prevalence of Hepatitis B among municipal waste collectors was very low in Penang as compared to other studies done in other countries. Most of them had poor knowledge in regards of Hepatitis B. Nevertheless, the attitude and practices in the prevention of Hepatitis B were good. Health educational campaign to increase the waste collectors' awareness on the disease is essential.

\section{Acknowledgements}

We would like to acknowledge the local municipal council and contractors for the support given to conduct this study. Much appreciation is given to the municipal waste collectors for their participation in the study.

\section{Funding}

This study was funded under a research grant from RCSI \& UCD Malaysia Campus, with the grant no. of PMC RC-14. 


\section{Competing Interests Statement}

The authors declare that there are no competing or potential conflicts of interest.

\section{References}

Abdul Rauf, M. U., Saleem, M. D., Anwer, M. O., Ahmed, G., Aziz, S., \& Memon, M. A. (2013). HIV, Hepatitis B and Hepatitis C in garbage scavengers of Karachi. Journal of Pakistan Medical Association, 63, 798-802.

Ajzen, I. (1991). The Theory of Planned Behavior. Organizational Behavior and Human Decision Processes, 50, 179-211. https://doi.org/10.1016/0749-5978(91)90020-T

Ajzen, I. (1993). Attitude Theory and the Attitude-Behavior Relation. In New Directions in Attitude Measurement. New York.

Barloa, E. P., Lapie, L. P., \& de la Cruz, C. P. P. (2016). Knowledge, Attitudes, and Practices on Solid Waste Management among Undergraduate Students in a Philippine State University Knowledge, Attitudes, and Practices on Solid Waste Management among Undergraduate Students in a Philippine State University. Journal of Environment and Earth Science, 6(June).

Bleck, D., \& Wettberg, W. (2012). Waste collection in developing countries - Tackling occupational safety and health hazards at their source. Waste Management, 32(11), 2009-2017. https://doi.org/10.1016/j.wasman.2012.03.025

Centers for Disease Control and Prevention. (2001). Updated U. S. Public Health Service Guidelines for the Management of Occupational Exposures to HBV, HCV, and HIV and Recommendations for Postexposure Prophylaxis. $M M W R, 50(11)$.

Corrao, C. R. N., Cimmuto, A. Del, Marzuillo, C., Paparo, E., \& Torre, G. La. (2013). Association between Waste Management and HBV among Solid Municipal Waste Workers : A Systematic Review and Meta-Analysis of Observational Studies. The Scientific World Journal. https://doi.org/10.1155/2013/692083

Dounias, G., Kypraiou, E., Rachiotis, G., Tsovili, E., \& Kostopoulos, S. (2005). Prevalence of hepatitis B virus markers in municipal solid waste workers in Keratsini (Greece). Occupational Medicine, 55(1), 60-63. https://doi.org/10.1093/occmed/kqi007

Haq, N., Hassali, M. A., Shafie, A. A., Saleem, F., Farooqui, M., \& Aljadhey, H. (2012). A cross sectional assessment of knowledge, attitude and practice towards Hepatitis B among healthy population of Quetta, Pakistan. BMC Public Health, 12. https://doi.org/10.1186/1471-2458-12-692

Ilyas, M., Iftikhar, M., Rasheed, U., \& Yasmin, S. (2012). Prevalence of Hepatitis B virus infection among population of factory workers in Gujranwala (Punjab) Pakistan. BIOLOGIA (PAKISTAN), 58, 47-52.

Khouri, M. El, Duarte, L. S., Ribeiro, R. B., Ferraz, F., Marcelo, L., Camargo, A., ... Corbett, P. (2005). Seroprevalence of Hepatitis B virus and Hepatitis C virus in Monte Negro in the Brazilian Western Amazon Region. Clinics, 60(1), 29-36. https://doi.org/10.1590/S1807-59322005000100007

Laor, P., Suma, Y., Keawounglek, V., Hongtong, A., Apidechkul, T., \& Pasukphun, N. (2018). Knowledge, attitude and practice of municipal solid waste management among highland residents in Northern Thailand. Journal of Health Research, 32(2), 123-131. https://doi.org/10.1108/JHR-01-2018-013

Luksamijarulkul, P., Sujirarat, D., \& Charupoonphol, P. (2008). Risk behaviors, occupational risk and seroprevalence of Hepatitis B and A infections among public cleansing workers of Bangkok Metropolis. Hepatitis Monthly, 8(1), 35-40.

Marinho, T. A., Lopes, C. L. R., Teles, S. A., Matos, M. A. de M., Matos, M. A. D., Kozlowski, A. G., ... Martins, R. M. B. (2014). Epidemiology of hepatitis B virus infection among recyclable waste collectors in central Brazil. Revista Da Sociedade Brasileira de Medicina Tropical, 47(1), 18-23. https://doi.org/10.1590/0037-8682-0177-2013

Raihan, R. (2016). Hepatitis in Malaysia: Past, Present, and Future. Euroasian Journal of Hepato-Gastroenterology, 6(1), 52-55. https://doi.org/10.5005/jp-journals-10018-1167

Shiferaw, Y., Abebe, T., \& Mihret, A. (2011). Hepatitis B virus infection among medical waste handlers in Addis Ababa, Ethiopia. BMC Research Notes, 4(479). https://doi.org/10.1186/1756-0500-4-479

Tsovili, E., Rachiotis, G., Symvoulakis, E. K., Thanasias, E., Giannisopoulou, O., Papagiannis, D., ... Hadjichristodoulou, C. (2014). Municipal waste collectors and hepatitis B and C virus infection: a cross-sectional study. Le Infezioni in Medicina, 271-276. 
World Health Organization. (2017). Global Hepatitis Report, 2017. WHO. Geneva, Switzerland. http://doi.org/ISBN 978-92-4-156545-5

Yang, Y., Yan, M., Yue, M., Wang, X., Zhang, W., Li, J., \& Li, S. (2015). Prevalence of Hepatitis B and Knowledge About Hepatitis B Among Migrant Workers in Shandong Province, China : A Cross-Sectional Study. Iran Red Crescent Med J, 17(4), e26725. https://doi.org/10.5812/ircmj.17(4)2015.26725

Yusuf, R. O., Sawyerr, H. O., Adeolu, A. T., Habeeb, L. M., \& Abolayo, T. T. (2018). Seroprevalence of Hepatitis B Virus and Compliance to Standard Safety Precautions among Scavengers in Ilorin Metropolis, Kwara State, Nigeria. J Health Pollution, 19(September). https://doi.org/10.5696/2156-9614-8.19.180914

\section{Copyrights}

Copyright for this article is retained by the author(s), with first publication rights granted to the journal.

This is an open-access article distributed under the terms and conditions of the Creative Commons Attribution license (http://creativecommons.org/licenses/by/4.0/). 